\title{
GIS-Based Surface Runoff Modeling Using Empirical Technique For A River Basin In South India
}

\author{
B. Prabhu Dass Batvari* and K. Nagamani**† \\ *Centre for Earth and Atmospheric Sciences, Sathyabama Institute of Science and Technology, Chennai-600119, India \\ **Centre for Remote Sensing \& Geoinformatics, Sathyabama Institute of Science and Technology, Chennai-600119, \\ India \\ $\dagger$ Corresponding author: K. Nagamani: nagamani@sathyabama.ac.in
}

Nat. Env. \& Poll. Tech.
Website: www.neptjournal.com
Received: 14-07-2021
Revised: 26-08-2021
Accepted: 03-09-2021
Key Words:
Rainfall runoff
Curve number
GIS
Land use

\begin{abstract}
Precipitation is the primary source of fresh water in the world. Surface runoff will happen when the amount of rainfall is greater than the soil's infiltration capacity. In most water resource applications, runoff is the most important hydrological variable. Aside from these rainfall characteristics, there are a number of catchment-specific elements that have a direct impact on runoff amount and volume. This research focuses on estimating surface runoff over the lower Vellar basin, a river basin in the southern part of India, by integrating Soil Conservation Service-Curve Number (SCS-CN) method with GIS. This technique is one of the most common methods used by hydrologists for estimating surface runoff. Curve Number $(\mathrm{CN})$ is an index established by the Natural Resource Conservation Service (NRCS) to denote the potential for stormwater runoff. The nature of the watershed is explored first by creating land use and land cover pattern followed by the preparation of slope, drainage, and location maps. The area taken for this study is the lower Vellar basin situated in the Cuddalore District of Tamil Nadu, India. The curve number is analyzed using the rainfall data of 15 years (2001-2015) and the runoff is being calculated. The watershed pattern of the study area is also explored being analyzed and executed. Preservation of the runoff water is also discussed.
\end{abstract}

\section{INTRODUCTION}

Water is the most important element for all living things; without water, there would be no vegetation on the Earth, no oxygen for animals to breathe, and the world would look very different than it does now. Water is required for human health and the preservation of the environment, and it should be valued and protected as a valuable resource. However, as a result of pollution, clean water is becoming increasingly scarce (Gagan et al. 2016).

The oceans hold around 97 percent of the world's water. Saltwater covers about 1.4 billion cubic kilometers. Freshwater makes up only $3 \%$ of the total, and it is found in rivers, glaciers, and lakes. Even though there is abundant fresh water all across the world, there are some areas that are too dry and do not receive enough rain. Water scarcity is a prevalent issue in developing countries due to population expansion. Many areas lack sufficient water because people exhaust it. Water moves in a continuous cycle, never disappearing or ceasing to exist, but shifting from solid to liquid to gas. While some rainwater returns to the atmosphere, the majority of it enters the ground through aquifers.

Runoff is the most significant hydrological factor used in more applications of water resources. Its incidence and amount are based on the features of rainfall occurrence, i.e. the length, intensity and circulation. In addition to these rainfall features, there are numerous catchment-specific variables that directly affect the incidence and quantity of runoff. There are several methods existing for rainfall-runoff modeling. Soil Conservation Services and Curve Number (SCS-CN) techniques offer an empirical relationship to estimate original abstraction and runoff as soil type and land use function. Curve Number $(\mathrm{CN})$ is an index created by the Natural Resource Conservation Service (NRCS) to represent the potential of a drainage region for stormwater runoff (Hailu et al. 2018, Sishah 2021). The U.S. Soil Conservation Service at the Department of Agriculture initially created the SCS-CN technique (Van Dijk 2010, Abon et al. 2011, Steenhuis et al. 1995).

The $\mathrm{CN}$ for a watershed is evaluated using a mixture of land use, antecedent soil moisture condition (AMC), and soil. There are four types of hydrologic soils: A, B, C, and D. Group A has a high rate of infiltration, while Group D has a low rate of infiltration. The Soil Conservation Service Curve Number (SCS-CN) method is widely used to forecast direct runoff volume for a specific rainfall event (Mishra \& Singh 1999, King \& Balogh 2008, Elhakeem \& Papanicolaou 2009, Romero et al. 2007). 
Recent sophisticated methods such as remote sensing and the Geographic Information System (GIS) are therefore involved in the compilation, storage, and evaluation of spatial and temporal allocation information. These techniques are currently being used to address watershed-related challenges such as watershed planning, growth, and management, with the goal of harnessing all-natural resources for long-term development (Verma et al. 2016, Rawat \& Singh 2017, Tiwari et al. 2017). Thus, Geographic Information Systems (GIS) and Remote Sensing is the main tool to provide the foundation for effective water resource management. (Gupta et al. 2004, Frevert \& Singh 2002, Siddi Raju et al. 2018, Mahboubeh et al. 2012, Sharma et al. 2008, Ruslin Anwar 2011).

\section{MATERIALS AND METHODS}

\section{Study Area}

The Vellar River is situated in the Cuddalore district which lies in the coastal belt of Tamil Nadu. It is one of the many ephemeral rivers in the area; it runs from west to east and blends with the sea south of Porto-Novo. The lower Vellar sub basin comprises the Perumal Eri (lake) watershed and is connected by the Bay of Bengal to the east. The parts of the lower Vellar watershed (Study area) comprise the catchment and command areas of Perumal 'Eri' extended up to the Bay of Bengal in the East. Cuddalore is the district headquarters, which is well connected by both rail and roadways. The study area (lower Vellar watershed) is bounded to the north by the Ponnaiyar watershed, to the south by the Vellar watershed, and to the east by the Bay of Bengal. The pilot study area (lower Vellar watershed) lies between north latitudes $11^{\circ}$ $30^{\prime} 10^{\prime}$ ' and $11^{\circ} 42^{\prime} 16^{\prime \prime}$ and east longitudes $79^{\circ} 30^{\prime} 00^{\prime \prime}$ and $79^{\circ} 46^{\prime} 6^{\prime \prime}$ and is covered by the survey of India toposheet No. $58 \mathrm{M} / 10$. The total study area taken is said to be 1784 $\mathrm{km}^{2}$, and a Google Earth snapshot of the entire study area is shown in Fig.1.

\section{Data Sources}

IRS LISS-III data was used for the LULC classification. Land use/land cover classes in the current study region have been identified, and the LULC map is shown in Fig. 2. Daily rainfall data ((2001- 2015) was used in this study, and the data was collected from IMD, Chennai. Soil information was obtained from the National Bureau of Soil Survey and Land Use Planning (NBSS \& LUP). The study area's Digital Elevation Model (DEM) and slope and elevation map were obtained from SRTM (Shuttle Radar Terrain Mission) and is shown in Fig. 3 and 4.

\section{Runoff Calculation}

The equation of the runoff curve number is:

$$
\begin{gathered}
Q=\frac{\left(P-I_{a}\right)^{2}}{\mathbf{P}-I_{a}}+\mathbf{S} P>I_{a} \\
Q=0 \quad P \leq I_{a}
\end{gathered}
$$

Where: $\mathrm{Q}=$ Actual Direct Runoff $(\mathrm{mm}), \mathrm{P}=$ Total Rainfall $(\mathrm{mm}), \mathrm{I}=$ Initial Abstraction, $\mathrm{S}=$ Watershed Retention (mm). IA (I) and WR (S) can be related to each other by analyzing rainfall-runoff data for the sub-watersheds. The empirical relation between I and S may be stated as follows:

$$
\mathrm{I}=0.2 \mathrm{~S}
$$

Therefore, applying Equation 2 on Equation 1

$$
\mathrm{Q}=\frac{(\mathbf{P}-\mathbf{0 . 2 S})^{2}}{\mathbf{P}+\mathbf{0 . 8 S}} \quad \mathrm{P} \geq 0.2 \mathrm{~S}
$$

Retention parameter $(\mathrm{S})$ is dependent upon soils, land use, and slope, and it is defined as-

$$
S=25.4\left(\frac{1000}{\mathrm{CN}-10}\right)
$$

Where $\mathrm{CN}$ is the day's Curve Number, a dimensionless runoff index determined by land use, hydrological soil groups (HSG), and antecedent moisture content (AMC).

The curve number $(\mathrm{CN})$ depends on the permeability of the soil, its usage, and its previous moisture content. The daily retention value adjusted according to water content is calculated by rearranging equation 4 and inserting the retention parameter (explained in detail below) calculated for the soil which is completely saturated.

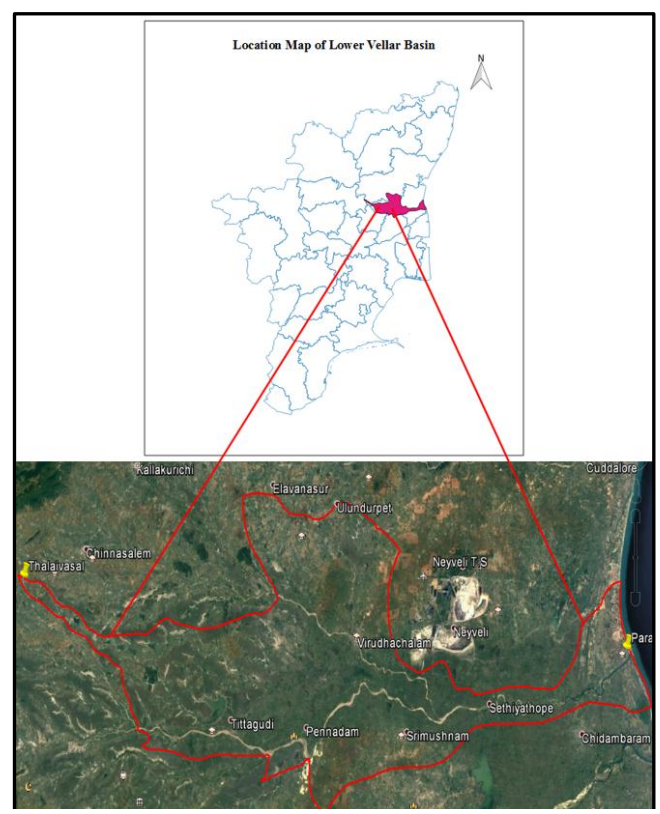

Fig. 1: Study Area-Vellar River Basin 


$$
S=\left(\frac{25400}{\mathrm{CN}}\right)-254
$$

The curve number $(\mathrm{CN})$ depends on the permeability of the soil, its usage, and its previous moisture content. The equation for the derivation of $\mathrm{CN}$ is:

$$
\mathrm{CN}=\frac{\sum(P 1 A 1+P 2 A 2+\cdots+P n A n)}{\sum A}
$$

This equation calculates $\mathrm{CN}$ values based on land use and land cover classes and hydrological soil groups, where a $5 \%$ slope is under consideration.

The present equation calculates $\mathrm{CN}$ for AMC 2. Variability in $\mathrm{CN}$ consequences related to moisture conditions of the soil, precipitation duration and intensity, total precipitation, cover density, temperature, and growth stage. These sources of variableness are collectively named as Antecedent Runoff Condition (ARC). The ARC is classified into three classes: $\mathrm{CN} 2$ for normal conditions, $\mathrm{CN} 1$ for arid conditions, and $\mathrm{CN} 3$ for humid conditions. $\mathrm{CN} 1$ and $\mathrm{CN} 3$ can be calculated with the following mathematical equations.

$$
\begin{gathered}
\mathrm{CN} 1=\frac{4.2 C N 2}{10-0.058 C N 2} \\
\mathrm{CN} 3=\frac{23 C N 2}{10+0.13 C N 2} \\
\mathrm{~S}=\left(\frac{25400}{\mathrm{CN} 1}\right)-254 \text { AMC } \leq 13 \\
\mathrm{~S}=\left(\frac{25400}{\mathrm{CN} 3}\right)-254 \text { AMC }>28 \\
\mathrm{~S}=\left(\frac{25400}{\mathrm{CN} 2}\right)-25428<\mathrm{AMC}>13
\end{gathered}
$$

Either $\mathrm{CN} 1 / \mathrm{CN} 2 / \mathrm{CN} 3$ is used for the calculation of Watershed Retention (S) using Equation 5 based on the AMC values.

The run-off relationship was calculated using a number of retention criteria. The initial abstraction, Ia, may be

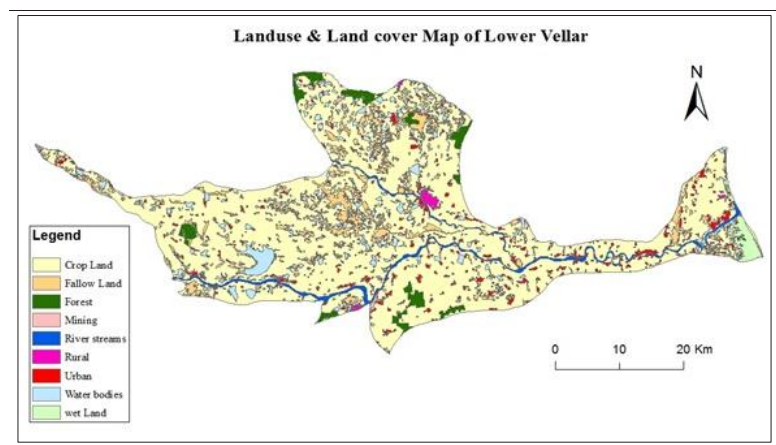

Fig. 2: Land use and Land cover classification of the Vellar regarded as the borderline between the size of the storm that creates runoff and the size of the storm that creates no runoff. Retention at its highest level, S, is dependent upon the soil cover compound and, in principle, must not differ from one storm to the next. It is greater than the initial abstraction, so Ia $+\mathrm{S}$ gives the maximum potential loss. The difference between rainfall and runoff $(\mathrm{P}-\mathrm{Q})$ is used to calculate the loss. When equation (9) is substituted for $\mathrm{Q}$, the result is

$$
\text { LosS }=P-Q=P-\frac{\left(P-I_{\mathrm{a}}\right)^{2}}{\left(P-I_{\mathrm{a}}\right)+S}
$$

Following the multiplication of both terms on the righthand side by: $\mathbf{1}=\frac{\left(\boldsymbol{P}-\boldsymbol{I}_{\mathrm{a}}\right)+\boldsymbol{S}}{\left(\boldsymbol{P}-\boldsymbol{I}_{\mathrm{a}}\right)+\boldsymbol{S}}$

With certain manipulation this becomes:

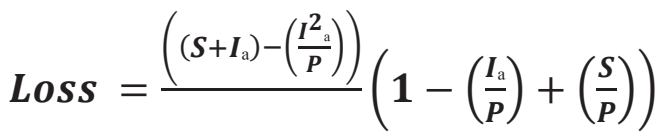

The terms in the denominator with $\mathrm{P}$ in the denominator approach zero as $\mathrm{P}$ approaches large, where large is defined as $\mathrm{P}$ being significantly greater than the maximum possible retention $(\mathrm{S})$.

$$
\text { Loss }=\mathrm{S}+\mathrm{I}_{\mathrm{a}}
$$

The parameter F is the storm's true retention, which is higher than the early abstraction. That is, the total actual retention is equal to the sum of the initial abstraction and the actual retention $(\mathrm{Ia}+\mathrm{F})$.

\section{Model Calculation}

Let the Rainfall for five days be 40.9, 60.4, 70.2, 0, and 30.8 . The rainfall on the $6^{\text {th }}$ day is 25.5 .

AMC (Antecedent Moisture Content) for day 6 can be calculated using the following formula (weighted average)

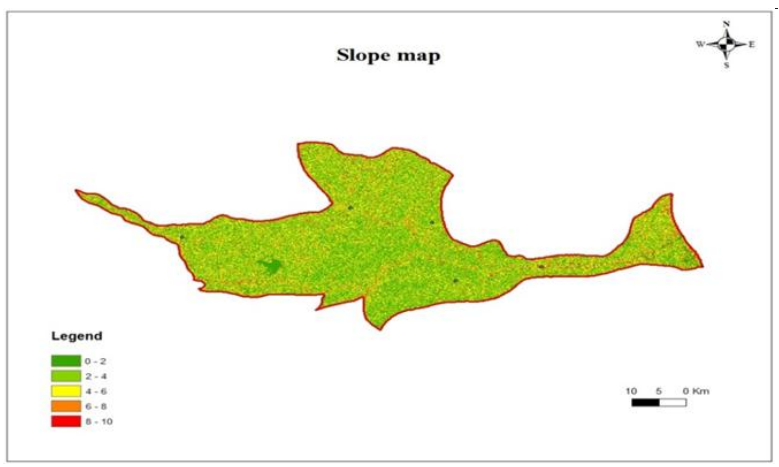

Fig. 3: Lower Vellar basin Slope map 
$\mathrm{AMC}=(0.9 * \mathrm{R} 1)+\left((0.9)^{\wedge} 2 * \mathrm{R} 2\right)+\ldots .+\left((0.9)^{\wedge} \mathrm{n} * \mathrm{Rn}\right)$

Here, R1, R2, Rn represents rainfall in $\mathrm{mm}$

$=\left(0.9^{*} 40.9\right)+\left(0.9^{\wedge} 2 * 60.4\right)+\left(0.9^{\wedge} 3^{*} 70.2\right)+\left(0.9^{\wedge} 4^{*} 0\right)+\left(0.9^{\wedge}\right.$ $5 * 30.8)=142.68$

Now, $\mathrm{AMC}>28$, we consider $\mathrm{CN} 3$ (wet) $(\mathrm{CN} 3=91.89)$

$\mathrm{S}=(25400 / 91.89)-254=22.42$

$\mathrm{I}=0.2 * 22.42=4.48$

$\mathrm{P}-\mathrm{I}=$ Daily rainfall $-4.48=25.5-4.48=21.02$

$\mathrm{Q}=(\mathrm{P}-\mathrm{I})^{2} / \mathrm{P}+0.8 * \mathrm{~S}=21.02^{2} / 25.5+0.8 * 22.42=10.17 \mathrm{~mm}$

The runoff of day 6 is $\mathbf{1 0 . 1 7} \mathbf{m m}$.

\section{RESULTS AND DISCUSSION}

\section{Land Use}

According to the LULC map of the lower Vellar basin, the majority of the area was classified as fallow land and cropland, implying that there may be more infiltration and consequently lesser runoff. Out of the overall area (1784 $\mathrm{km}^{2}$ ), $2 \mathrm{~km}^{2}$ have been designated as mining areas (Fig. 2), which will manage surface runoff.

\section{Slope Map}

The slope is one of the deciding factors in surface runoff. SRTM elevation data acquired from USGS Earth Explorer was used. ArcMap 10.3 is the software used. The slope map findings for the chosen research area are less than 5\%. As a result, it is not taken into account. Fig. 3 shows the slope map of the research area.

\section{Elevation Map}

The most common type of map used to depict elevation is a topographical map. In Geographic Information Systems (GIS), digital elevation models (DEM) are commonly used to represent the surface (topography) of a location using a raster (grid) dataset of elevations. The color difference in the map depicts the study area's high to low elevation values. The elevation map is created using SRTM elevation data. Fig. 4 shows an elevation map of the research area.

\section{Contour Map}

A contour map represents the elevation of the particular area within the elevation lines drawn on it. The contour interval is the difference in height between successive contour lines on a contour map. A two-variable function's contour line is often a curve that connects points where the function has the same value. The presented map's contour interval is $20 \mathrm{~m}$. The study area's western side is sloppier than the lower Vellar basin's east side, and the distance between each contour is higher, implying that the study area is practically plain. Fig. 5 shows the contour map of the research region.

\section{Rainfall and Runoff Kuppanatham}

The total rainfall recorded at Kuppanatham is $18191.4 \mathrm{~mm}$, with a runoff of $8787.48 \mathrm{~mm}$. Rainfall and runoff averages $1212.8 \mathrm{~mm}$ and $585.83 \mathrm{~mm}$, respectively. In 2015, the largest rainfall was recorded, as well as the highest runoff. In the year 2012, the lowest rainfall was recorded, and the lowest runoff was recorded in the year 2003. This was because of the driest period, which lasted from 2001 to 2003. As a result, the actual amount of rain that fell throughout these years would sweep in. Despite the fact that rainfall was minimal in 2012, the rainfall in 2011 was adequate to recharge the groundwater potential. The runoff in 2012 is higher than in 2003. Data 2 contains the yearly runoff table for station Kuppanatham, while Fig. 6 and Fig. 7 depict the rainfall-runoff distribution and relationship.

\section{Rainfall and Runoff Memathur}

The total rainfall in Memathur is $17613.6 \mathrm{~mm}$, with an

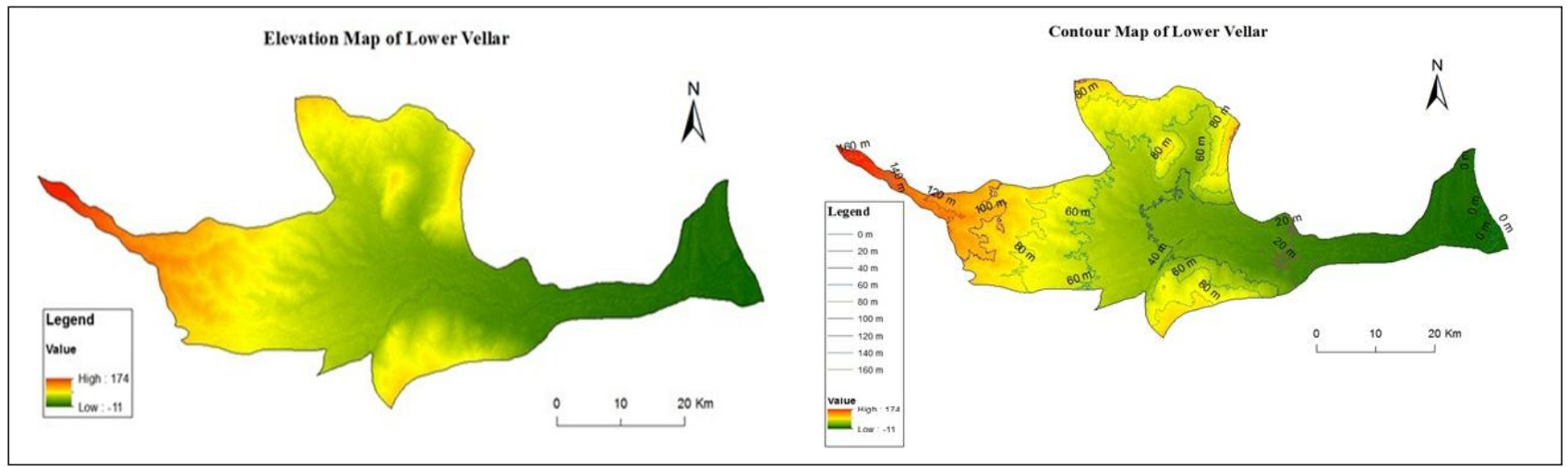

Fig. 4: Elevation Lower Vellar basin

Fig. 5: Contour Lower Vellar basin 
equivalent runoff of $8091.09 \mathrm{~mm}$. Rainfall and runoff averages $1174.2 \mathrm{~mm}$ and $539.41 \mathrm{~mm}$, respectively.

The year with the high rainfall was 2015, and the year with the highest runoff was 2005. In the year 2012, the lowest rainfall was recorded, as well as the lowest runoff. Because the rainfall in Memathur was higher in all of the years from 2001 to 2005, the year 2005 had the largest runoff (Fig. 8 \& 9).

\section{Rainfall and Runoff Sethiyathope}

The total rainfall at Sethiyathope is $21150 \mathrm{~mm}$, while the runoff is also $21150 \mathrm{~mm}$. The average rainfall is $1410 \mathrm{~mm}$, while the average runoff is $716.02 \mathrm{~mm}$. In 2005, the largest rainfall was recorded, as well as the highest runoff. The year 2012 saw the lowest rainfall, while 2001 saw the lowest runoff. Table 2 contains the yearly runoff table for station Sethiyathope, as well as graphs depicting the rainfall-runoff relationship and distribution. Fig. 10 and 11 show the graphs depicting the rainfall-runoff relationship and distribution.

\section{Rainfall and Runoff Srimushnam}

In Srimushnam, the total rainfall reported is $17510.3 \mathrm{~mm}$, with a runoff of $8531.86 \mathrm{~mm}$. Rainfall and runoff average $1167.4 \mathrm{~mm}$ and $568.79 \mathrm{~mm}$, respectively. The maximum rainfall and runoff were both recorded in the year 2003. The lowest rainfall and runoff were both recorded in the year 2012 (Fig. $12 \& 13$ ).

\section{Rainfall and Runoff Virudhachalam}

The total amount of rainfall in Virudhachalam is $18815.1 \mathrm{~mm}$, with a runoff of $8744.22 \mathrm{~mm}$. The average rainfall is 1254.3 $\mathrm{mm}$, while the average runoff is $582.95 \mathrm{~mm}$. In 2005, the largest rainfall was recorded, as well as the highest runoff. In the year 2014 the lowest rainfall, as well as the lowest runoff has been recorded (Fig. $14 \& 15$ ).

\section{Rainfall and Runoff relationship in Lower Vellar basin}

In 2005, the lower Velar basin received the most average rainfall $(1758.92 \mathrm{~mm})$. In 2012, the lower Vellar basin's average rainfall was at its lowest $(750.84 \mathrm{~mm})$. The highest

Table 1: Land Use and Land Cover

\begin{tabular}{|lll|}
\hline S.No & Land Use & Area $\left[\mathrm{km}^{2}\right]$ \\
\hline 1 & Water bodies & 91.5 \\
2 & Fallow Land & 161.4 \\
3 & Forest & 49.5 \\
4 & Urban & 77.5 \\
5 & Rural & 9 \\
6 & Crop Land & 1321.8 \\
7 & River Stream & 47.7 \\
8 & Mining & 2 \\
9 & Wet Land & 23.8 \\
\hline
\end{tabular}

Table 2: Rainfall and Runoff in Vellar Basin

\begin{tabular}{|c|c|c|c|c|c|c|c|c|c|c|}
\hline & \multicolumn{2}{|c|}{ Kuppanatham } & \multicolumn{2}{|c|}{ Memathur } & \multicolumn{2}{|c|}{ Seithiyathope } & \multicolumn{2}{|c|}{ Srimushnam } & \multicolumn{2}{|c|}{ Virudhchalam } \\
\hline Year & Rainfall & Runoff & Rainfall & Runoff & Rainfall & Runoff & Rainfall & Runoff & Rainfall & Runoff \\
\hline 2001 & 867.50 & 384.13 & 1186.00 & 516.16 & 927.70 & 309.98 & 962.80 & 446.00 & 989.10 & 386.62 \\
\hline 2002 & 918.70 & 411.69 & 1164.60 & 582.65 & 1141.10 & 594.46 & 1417.00 & 835.89 & 827.80 & 335.44 \\
\hline 2003 & 895.60 & 317.71 & 1200.00 & 447.80 & 954.40 & 315.02 & 2281.00 & 1569.95 & 932.50 & 330.73 \\
\hline 2004 & 1599.00 & 938.44 & 1149.00 & 550.98 & 1593.70 & 898.94 & 1801.00 & 1107.68 & 1503.70 & 755.39 \\
\hline 2005 & 1660.20 & 898.94 & 1576.00 & 919.93 & 2021.00 & 1177.52 & 1788.50 & 992.67 & 1748.90 & 938.67 \\
\hline 2006 & 897.00 & 330.11 & 905.00 & 335.09 & 1685.00 & 886.82 & 1292.00 & 596.86 & 1029.30 & 362.06 \\
\hline 2007 & 1156.00 & 618.04 & 1021.00 & 469.63 & 1578.00 & 935.95 & 1046.00 & 417.79 & 1139.10 & 596.58 \\
\hline 2008 & 1365.70 & 607.00 & 1248.00 & 533.29 & 1848.00 & 1134.72 & 1252.50 & 559.72 & 1511.70 & 677.10 \\
\hline 2009 & 1150.90 & 466.48 & 1245.00 & 632.20 & 1388.50 & 635.56 & 755.00 & 282.67 & 1294.20 & 538.57 \\
\hline 2010 & 1615.80 & 784.16 & 1557.00 & 750.21 & 1562.50 & 787.27 & 1106.00 & 482.37 & 1711.10 & 872.05 \\
\hline 2011 & 1456.00 & 805.43 & 961.00 & 496.21 & 1207.00 & 632.81 & 853.00 & 299.01 & 1374.60 & 740.76 \\
\hline 2012 & 752.80 & 325.42 & 747.00 & 304.74 & 832.00 & 392.89 & 414.00 & 119.64 & 1008.40 & 475.35 \\
\hline 2013 & 1236.70 & 601.32 & 952.00 & 310.82 & 1161.70 & 453.09 & 650.00 & 129.19 & 1224.10 & 541.18 \\
\hline 2014 & 873.90 & 343.98 & 936.00 & 339.29 & 1256.80 & 500.21 & 832.00 & 298.54 & 831.30 & 306.45 \\
\hline 2015 & 1745.60 & 954.64 & 1766.00 & 902.10 & 1992.60 & 1085.03 & 1059.50 & 393.88 & 1689.30 & 887.27 \\
\hline
\end{tabular}




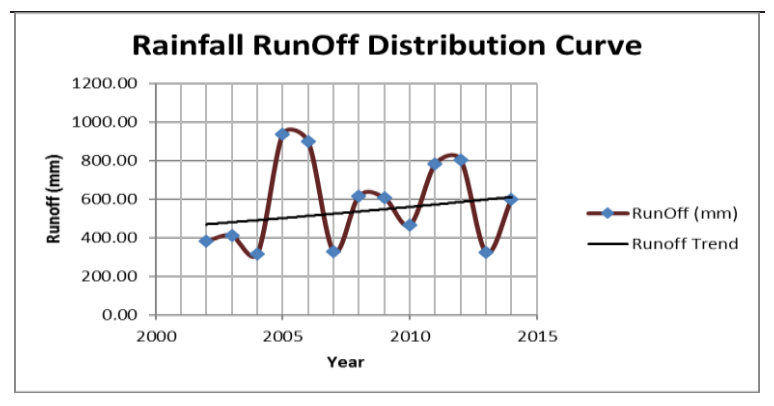

Fig. 6: Trend line of runoff Kuppanatham.

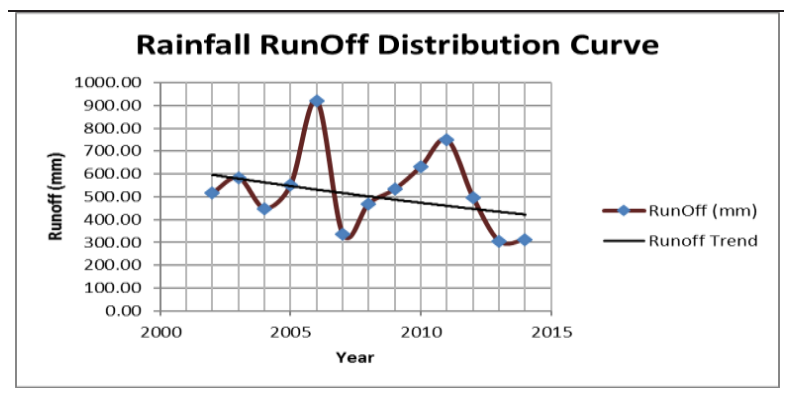

Fig. 8: Trend line of runoff decreased over years in Memathur.

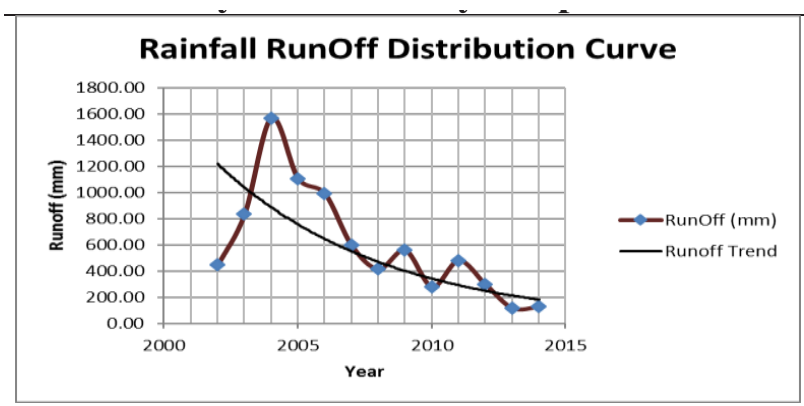

Fig. 10: Trend line of runoff increased over years in Sethiyathope.

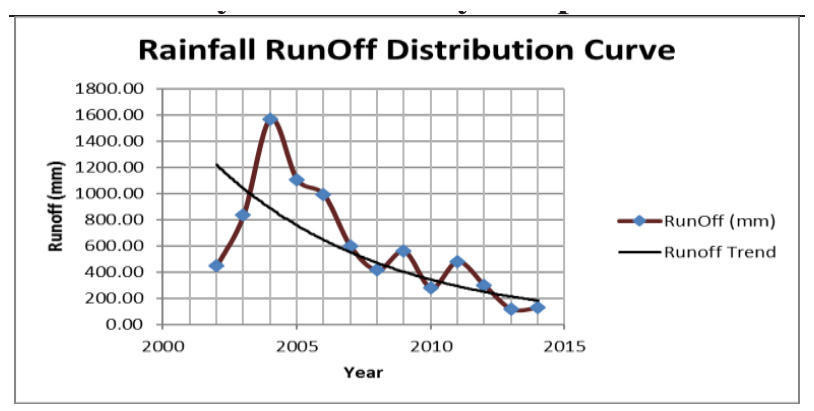

Fig. 12: Trend line of runoff tremendously decreased over years in Srimushnam.

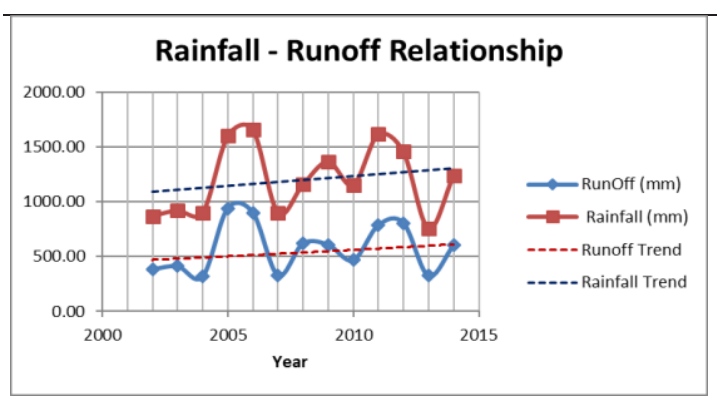

Fig.7: Positive correlation between rainfall and runoff in Kuppanatham.

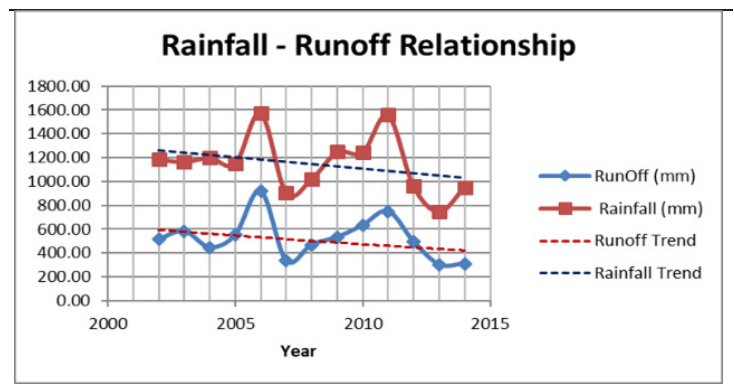

Fig. 9: Positive correlation between rainfall and runoff Memathur.

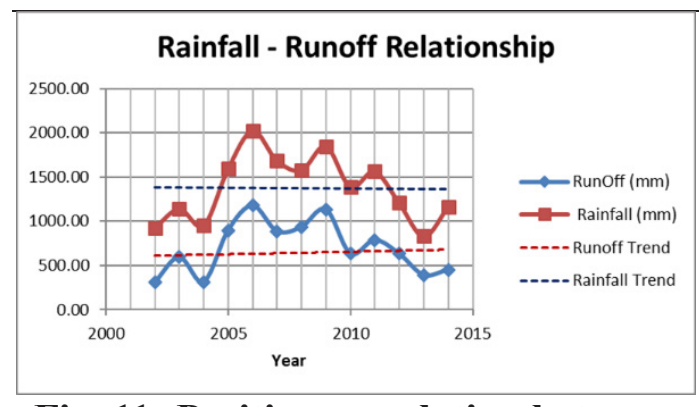

Fig. 11: Positive correlation between rainfall and runoff in Sethiyathope.

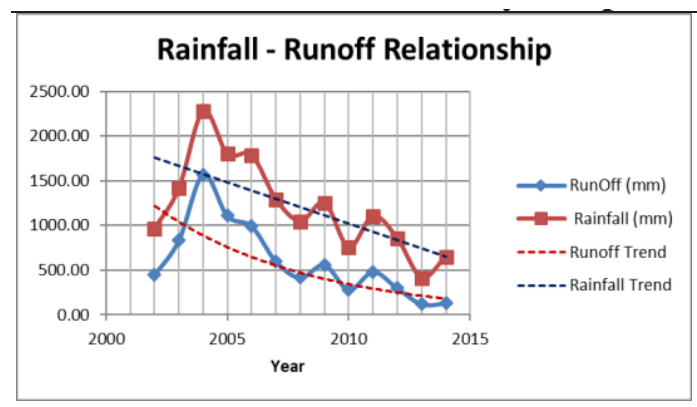

Fig. 13: Positive correlation between rainfall and runoff in Srimushnam. 


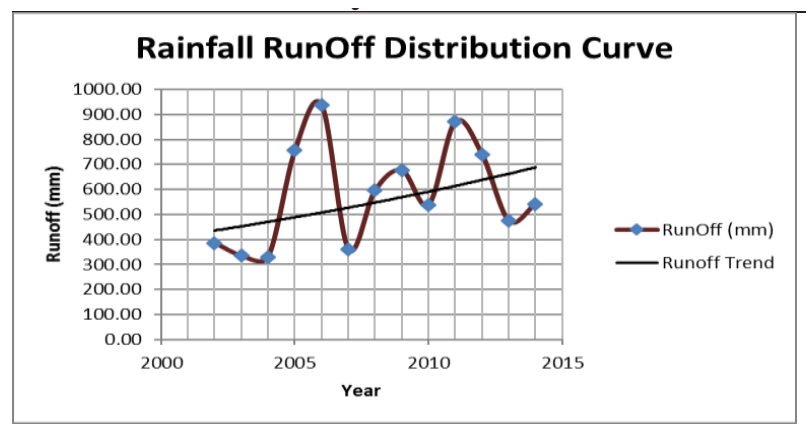

Fig. 14: The trend line of runoff increased over years in Virudhachalam

rainfall and runoff at Sethiyathope were both recorded at the same rainfall station. In Srimushnam, the Memathur rainfall station received the least rainfall and had the least drainage. In 2005, the lower Vellar basin's average runoff was at its highest $(985.5445 \mathrm{~mm})$. In 2012, the lower Velar basin's average rainfall was at its lowest $(323.6096 \mathrm{~mm})$.

\section{CONCLUSION}

This study mainly focuses on the estimation of losses due to surface runoff, which is favorably based on the soil infiltration characteristics and the continuation of rainfall occurrences. Knowledge of runoff from individual rainfall is required to evaluate the runoff behavior of a catchment area, as well as a sign of both the runoff-peaks that the water harvesting scheme's structure must be able to withstand the elements, as well as the required capacity for temporary surface runoff storage, such as a micro catchment system, the size of an infiltration pit. The watershed as a whole receives a good amount of rainfall. But, when compared to runoff, recharge is relatively low, as the terrain is comprised of crystalline rocks. By building agricultural ponds at suitable locations, this runoff potential can be used for artificial recharge. Additionally, buildings such as check dams are being built to store water. It will be useful for drinking water as well as agricultural applications during the hot summer days.

\section{REFERENCES}

Abon, C.C., David, C.P.C. and Pellejera, N.E.B. 2011. Reconstructing the tropical storm Ketsana flood event in Marikina River, Philippines. Hydrol. Earth Syst. Sci., 15: 1283-1289.

Elhakeem, M. and Papanicolaou, A.N. 2009. Estimation of the runoff curve number via direct rainfall simulator measurements in the state of Iowa, USA. Water Resour. Manag., 23: 2455-2473.

Frevert, D.K. and Singh, V.P. (ed). 2002. Mathematical Models of Large Watershed Hydrology. WRP, UK, pp.914.

Gagan, M., Amit, C., Avinash, K. and Ajendra, K. 2016. Impact of industrial effluent on groundwater and surface water quality: A case study of Dhampur region (UP), India. J. Chem. Pharm. Sci., 9(2): 709-713.

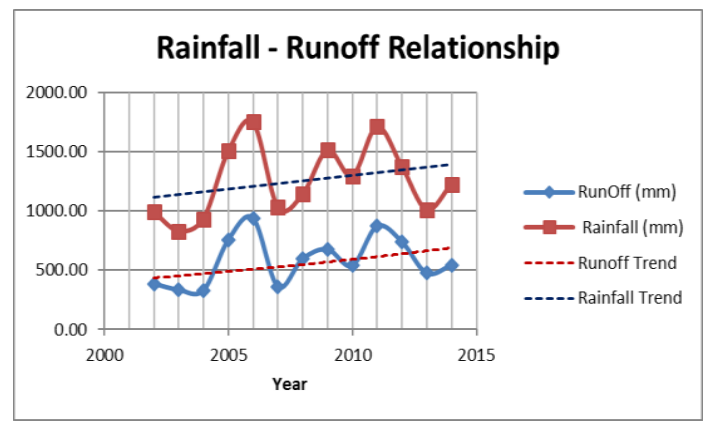

Fig. 15: Positive correlation between rainfall and runoff in Virudhachalam.

Gupta, H.V., Wagener, T. and Wheather, H.S. (ed). 2004. Rainfall-Runoff Modelling in Gauged and Ungauged Catchments. Imperial College Press, London, pp.306.

Hailu, R., Tolossa, D. and Alemu, G. 2018. Water institutions in the Awash basin of Ethiopia: The discrepancies between rhetoric and realities. Int. J. River Basin Manag., 16(1): 107-121.

King, K.W. and Balogh, J.C. 2008. Curve numbers for golf course watersheds. T. ASAE, 51: 987-996.

Mahboubeh, E., Ahmad, A., Nuruddin, B., Mohd Amin, B., Mohdsoom, A. and LiewJu, N. 2012. Runoff estimation in steep slope watershed with standard and slope-adjusted curve number methods. Pol. J. Environ. Stud., 21(5): 1191-1202

Mishra, S.K. and Singh, V.P. 1999. Another look at the SCS-CN method. J. Hydrol. Eng. ASCE., 4: 257-264.

Rawat, K.S. and Singh., S.K. 2017. Estimation of surface runoff from semi-arid ungauged agricultural watershed using SCS-CN method and earth observation data sets. Water. Conserv. Sci. Eng., 1: 233-247.

Romero, P., Castro, G., Go`ımez, J.A. and Fereres, E. 2007. Curve number values for olive orchards under different soil management. S. Sci. Soc. Am. J., 71: 1758-1769.

Ruslin Anwar, M. 2011. The rainfall-runoff model using the watershed physical characteristic approach. Int. J. Civil Environ. Eng., 11(6): 71-75.

Sharma, K.D., Sorooshian, S. and Wheater, H. (ed). 2008. Hydrological Modelling in Arid and Semi-Arid Areas.Cambridge University Press, New York, p. 223.

Siddi Raju, R., Sudarsana Raju, G. and Rajasekhar, M. 2018. Estimation of rainfall runoff using SCS-CN method with RS and GIS techniques for Mandavi Basin in YSR Kadapa District of Andhra Pradesh, India. Hydrospatial Anal., 2(1): 1-15.

Sishah, S. 2021. Rainfall runoff estimation using GIS and SCS-CN method for a wash river basin. Ethiopia. Int. J. Hydro., 5(1): 33-37.

Steenhuis, T.S., Winchell, M., Rossing, J., Zollweg, J.A. and Walter, M.F. 1995. SCS runoff equation revisited for variable-source runoff areas. J. Irrig. Drain. Eng. ASCE, 121: 234-238.

Tiwari, S., Kar, S.C., Bhatla, R. and Bansal, R. 2017. Annual Cycle of Temperature and Snowmelt Runoff in Satluj River Basin Using in Situ Data. In Pant, N.C., Ravindra, R., Srivastava, D. and Thompson, L.G. (eds), The Himalayan Cryosphere: Past and Present. Geological Society, London, Special Publications, pp. 1-20.

Van Dijk, A.I.J. M. 2010. Selection of an appropriately simple storm runoff model. Hydrol. Earth Syst. Sci., 14: 447-458.

Verma, D.K., Bhunia, G.S., Shit, P.K., Kumar, S., Mandal, J. and Padbhushan, R. 2016. Spatial variability of groundwater quality of Sabour block, Bhagalpur district (Bihar, India). Appl. Water Sci., 7(4): 1997-2008. 